\title{
Beyond African nationalism: Isaiah Shembe's hymns and African literature
}

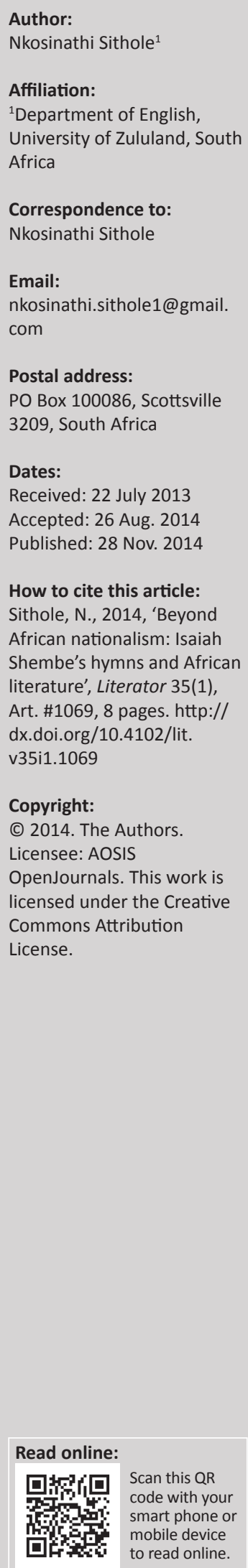

This article deals with Isaiah Shembe's hymns and proposes that they should be read as literature because, in them, Shembe employs a number of literary features. He also uses features of oral literature and uses the hymns to reflect on a number of issues that concerned him and his fellow black people. The hymns that are examined here are more akin to poetry than hymns in that Shembe uses them to engage with the issues of his time rather than to praise God. However, this does not mean that all the hymns should be misconstrued as political texts: They are generally songs of worship for the members to sing when praising God, yet Shembe also found in the genre of hymns a powerful medium for voicing his concerns as an African. Whilst other scholars have noted Shembe's concern with Zulu ethnicity and his contribution to Zulu literature, I suggest here a reading of the hymns that goes beyond Zulu ethnicity, looking at them as part of African literature since Shembe himself was not just concerned with the Zulus and their problems, but he was also concerned with the matters that concerned Africa as a whole.

Verby Afrika-nasionalisme: Jesaja Shembe se liedere en Afrika-literatuur. Hierdie artikel handel oor Isaiah Shembe se liedere en stel voor dat hulle as letterkunde gelees moet word want Shembe gebruik ' $n$ aantal kenmerke van die letterkunde en orale letterkunde daarin. Hy gebruik hulle om oor kwessies wat hy en ander swart mense bekommer, te besin. Die liedere is nader aan gedigte as aan godsdienstige gesange in die sin dat Shembe hulle gebruik om aktuele sake te bespreek eerder as net om God te loof. Dit beteken nietemin nie dat al die liedere as politieke tekste gesien moet word nie: Hulle is wel aanbiddingsgesange, maar Shembe het ook in die gesang 'n kragtige manier gevind om aan die kwessies wat hom as 'n Afrikaan na aan die hart gelê het, uitdrukking te gee. Terwyl ander geleerdes Shembe se betrokkenheid by Zoeloe-etnisiteit en sy bydrae tot die Zoeloe-letterkunde opgemerk het, stel ek 'n lees van die liedere voor wat verder as Zoeloe-etnisiteit gaan en beskou ek die liedere as deel van die letterkunde van Afrika. Dit is omdat Shembe nie net oor die sake van Zoeloe-mense begaan was nie, maar ook sake wat die hele Afrika raak.

\section{Introduction}

The hymns of Isaiah Shembe, said by Sundkler (1961:186) to be 'religious poetry of great beauty' and by Duncan Brown (1999:197) to be 'literary texts of great power and vision', provided a medium for Shembe to articulate his views and sense of self whilst at the same time engaging with the spiritual concerns of his followers and himself. This genre of hymns provided Isaiah Shembe with a space where he could challenge colonialism and white domination (amongst other things) whilst simultaneously providing texts that catered for his followers' spiritual needs. This paper seeks to locate Isaiah Shembe's hymns within the African and South African literary tradition. Whilst Gerard (1971:188) has noted the significance of Shembe's hymns in the beginning of isiZulu literature in his remark that ' $[i] \mathrm{t}$ is in his hymnal poetry that Shembe makes his unique contribution to Zulu literary history', I argue in this article that his contribution should be looked at in broader terms than simply 'Zulu literary history'. His work engaged with broader African issues, and what has been said about Shembe's concern with Zulu nationalism has been exaggerated or in some instances those who made such an argument misunderstood Shembe and his work.

I am particularly interested in how Shembe engaged with the 'burning issues' of his time whilst at the same time creating 'literary texts of great power and vision' as Brown (1999:197) claims he did. There are two reasons for choosing such an enterprise. The first one is that this article is part of a broader project which looks at politics and literature in black writing, comparing writers using English with those using isiZulu. This project is particularly concerned with the accusations made against literature in African languages that it is 'childish and immature' (see Sithole 2012) 
and that such immaturity and childishness emanate from the fact that writers in African languages eschew politics in their writings.

Related to the above is the claim that it was the censorship laws of apartheid that prevented writers from writing about the burning issues of the day and, by extension, writing pieces of work that could interest adult readers. One of the South African scholars who have lamented this weakness in South Africa's creative output in African languages is Eskia Mphahlele (1992), who states that:

\begin{abstract}
... it is one of our tragedies as a conquered people that what began as a vigorous literary movement in African languages, with an adult appeal, has in the last thirty years degenerated into writing that is published only for school children and is not particularly elevating ... Manuscripts that have an adult appeal and/or are highly political in content are suppressed. (p. 50)
\end{abstract}

Isaiah Shembe's hymns fall under the period that Mphahlele (1992) claims saw the beginning of a 'vigorous literary movement' in African languages, and it is my intention to explore the works of black writers of this period to ascertain how they negotiated 'literariness' with politics.

The second reason for looking at both the literary and sociological aspects of the hymns is that Isaiah Shembe's hymns are part of oral literature, and as Mathonsi (2004:46) has noted, '... oral literature is socially committed; nothing must be wasted, because life is short; education is not a privilege but a duty'. This means that reading Shembe's hymns without a consideration of their politics would be futile or a waste of time, as Mathonsi says, whilst limiting one's study to politics alone would be doing injustice to the hymns.

\section{A brief history of Isaiah Shembe and the composition of the hymns}

Ibandla lamaNazaretha was founded by Isaiah Shembe around 1910 in what is now KwaZulu-Natal. Today Ibandla lamaNazaretha is considered one of the biggest and most rapidly growing African Initiated Churches (AICs) in South Africa. Although it started as a local and ethnically specific church, Ibandla lamaNazaretha now has a strong national following, attracting members from all walks of life across ethnic groups. It also has members from as far afield as Mozambique and Zimbabwe. The church is rapidly growing in numbers. Whilst there are no reliable statistics, Nazaretha members are estimated at a few million. This growth, plus the church's '... success in creating a religious presence which is distinctively African', causes Gunner (2002:1) to see it as a '... force to be reckoned with in social, religious and political terms'.

Isaiah Shembe forged his church by blending Christian and African forms, many of the latter being downgraded and prohibited in mainstream churches. Isaiah Shembe's theology clashed with that of the nonconformist missionaries whose intention it was, as John and Jean Comaroff (1991) have noted, to:

... 'civilise' the native by remaking his person and his context; by reconstructing his habit and habitus; by taking back the savage mind from Satan, who had emptied it of all traces of spirituality and reason. (p. 238)

Some of the main issues of conflict were African song and dance, polygamy and recognition of the ancestors. One of the most significant expressive forms in the Nazaretha Church is umgidi (the sacred dance) in which the performers' dress includes loin skins, head ties and other attire made from animal hides. The sacred dance itself involves the beating of cowhide drums and the singing of hymns composed by Isaiah Shembe and is arguably an improvisation on the dances that took place in pre-colonial society, which were labelled 'uncivilised' and 'anti-Christian'.

Isaiah Shembe's hymns were meant to be sung by the members of his Ibandla lamaNazaretha when conducting services and when performing the sacred dance. They are now found in the church's hymnal (Shembe 1940), which was first published by Johannes Galilie Shembe in 1940. Isaiah Shembe composed 219 out of the 242 hymns in the hymnal that J.G. Shembe published in 1940 and that is still used, with some minor alterations, in the EBuhleni sect of Ibandla lamaNazaretha. ${ }^{1}$ The translation of the hymnal has recently been published by Carol Muller (2010).

Isaiah Shembe was a self-taught musician. Bongani Mthethwa, in an interview with Carol Muller, described Isaiah Shembe as '... a great maskanda musician of his time' (Muller 2010). He maintains that Shembe would '... lock himself inside the room and sing a song and rehearse how to crystallise it, as it were, into dance steps, and then take that and teach it to the people' (Muller 2010). Shembe was also, still in the words of Bongani Mthethwa:

... an excellent maskanda concertina player, and was able to play any instrument he laid his hands on. In the 1920s he started an instrumental ensemble in which the African flutes and the makweyana were played. (Muller 2010)

As Isaiah Shembe was not educated, he could not write his own hymns. He had scribes, normally young women members of his church, who would write down the hymns as they 'came' to him. I am putting 'came' in quotation marks because the generally accepted belief that Isaiah Shembe's hymns came with the messengers of heaven is partly true. I argue elsewhere (Sithole 2011) that this view deprives Shembe of his creativity and agency. Sundkler (1976) reports that Isaiah Shembe:

... would hear a woman's voice, often a girl's voice, singing new and unexpected words. He could not see her, but as he woke up from a dream or walked along the path in Zululand,

1 After the passing away of J.G Shembe Isaizh's son and successor there was a lo Ekuphakameni with a large group to establish a new village called Ebuhleni. Whils Amos composed no hymn of his own, Londa did, and the present leader, Vukile, also composes hymns. 
meditating, he heard that small voice, that clear voice, which gave him a new hymn. He had to write down the new words, while humming and singing the tune which was born with the words. (p. 186)

This shows the intricate relationship between orality and literacy that Barber and Furniss (2006) noted regarding literature in African languages. However, with regards to the hymns being brought by a 'woman's voice', I am doubtful. There are a number of hymns that seem to me to challenge this view as they are related to documented historical events, and there is no doubt that Shembe created the hymns as reflections to those events. A close and contextual reading of the hymns themselves negates the above understanding of the creation of the hymns. Hymn number 3 is a case in point: It is based on Shembe's prayer before he and his followers took on a journey to Nhlangakazi in 1923. He had been informed by the authorities that he could no longer undertake his pilgrimage to Nhlangakazi without prior permission by the magistrate (Papini 1999). When the time had come to go and there was no permit, Shembe decided to defiantly embark on his journey, and before he went, he said a prayer that was to form the basis for this hymn:

$\begin{array}{ll}\text { Nkosi Nkosi bubusise } & \text { Lord, Lord bless } \\ \text { Lobu buNazaretha } & \text { This Nazaretha Church } \\ \begin{array}{l}\text { Uchoboze izitha zabo } \\ \text { Zingabuvukeli. }\end{array} & \text { Crush its enemies } \\ \text { Vuka Vuka wena Nkosi } & \text { What they don't rise against it. } \\ \text { Mabulwelwe nguwe } & \text { Be the one that fights for it } \\ \text { Uzuhambe phambi kwabo } & \text { Travel ahead of it } \\ \text { Zingabuvukeli. } & \text { So they don't rise against it. } \\ \text { Noma siya entabeni } & \text { Even as we travel to the mountain } \\ \text { Owasikhethela yona } & \text { You chose for us } \\ \text { Ethiwa yiNhlangakazi } & \text { Called Nhlangakazi } \\ \text { Bungakhubeki. } & \text { Let it not falter. }\end{array}$

Clearly, this hymn speaks to Shembe's situation at the time of its composition. The 'enemies' about which it speaks are the state, the police and the missionaries (with the black believers); all those responsible for his predicament. Here Shembe was deliberating about his problem, namely being prohibited from undertaking a journey he had undertaken for the last five years or so. This hymn could then only have come from his mind, not brought by some spirits. Sundkler's quote above should be understood in terms of the composition of the interview from which it came: A white scholar interviewing a black religious leader (of a church that had for many years been subjected to scrutiny by the state) in a country ruled unfairly by a white government. The statement could have been invoked by Isaiah Shembe and J.G. Shembe to channel people's attention away from the political nature of some of the hymns.

Even though Shembe was not formally educated in mission schools, he realised the advantages of writing down his hymns, and before he taught himself to write, he used scribes to write down his hymns as mentioned above. Elizabeth Gunner (1988) says that:
One of Isaiah's first amanuenses was a young girl called Sangiwe Magwaza, who seems at one time to have attended Inanda Seminary. She was one of the small band who travelled indefatigably with Shembe and it is she who would be summoned to take down the hymns that came to Shembe, often in a dream. (p. 205)

Whilst most scribes were young girls who had been exposed to education like Sangiwe Magwaza, there were also male scribes. One of these was Phelalasekhaya Maphumulo. Muntuwezizwe Buthelezi's testimony in Oosthuizen and Hexham (1999) describes how hymn number 214 `Umkhululi Ufikile' [The liberator has arrived] was composed. He says that he and Maphumulo were sent by Isaiah Shembe to pray for the people at the mountain in Msinga called Entshoze. The two men went as instructed, and many people were healed. When they came back to Shembe and reported what had happened, Shembe was very pleased with them and 'blessed' them. He then sent Maphumulo to go fetch his writing material, and when he came back, Shembe told him to '... sit down facing the east and write what I say' (Oosthuizen \& Hexham 1999:179). And thus came hymn number 214:

Our Liberator has come

We the offspring of Dingane

We have heard him

The Liberator of the Zulus has come. ${ }^{2}$

\section{The external versus internal exegesis}

Perhaps due to the fact that he was well aware of the threat that his activities posed to the state, and also aware of how dangerous those were for his church and himself, Shembe created some of his hymns in such a way that it was impossible for his enemies to understand them fully without some background information. One such hymn is number 172 'Adedele Aphume' [Let them go out]. This hymn is one of those that do not resemble the Western hymn at all but is aligned even more with African or Zulu song. It is made of only four lines, and the fourth line repeats the second. This 'repeat' and the shortness of the hymn render it prone to repetition and rhythm that are characteristic of African indigenous songs and African oral literature in general:

$\begin{array}{ll}\text { Adedele Aphume } & \text { Let them go out } \\ \text { WeMashi } & \text { You Mashi } \\ \text { Akekho umsengi } & \text { The milker is away } \\ \text { WeMashi. } & \text { You Mashi. }\end{array}$

When read as it is, without any background knowledge to its creation, this hymn calls forth images of calves mooing, having been alienated from their mothers, and the cows being exploited for their milk. Readers who know the country life on which the poem is based cannot help but see in their mind's eye the cows with their udders filled

\footnotetext{
2.No isizulu version is offered in Oosthuizen and Hexham's (1999) book, and this stanza is different from the one in the hymnbook. The reason for this may be that the informant was just telling the story and inserted the hymn as he remembered the informant was just telling the story and inserted the hymn as he remembered
it. However, this English version can be translated as follows: Umkhululi wethu, usefikile/Thina nzalo kaDingane/ sesimzwile/Umkhululi wamaZulu ufikile.
} 
to the brim with milk. They can hear with their mind's ear the noise that both the cows and the calves make as they long for each other. However, a fuller understanding of the hymn only happens when one reads this song or hymn alongside Shembe's 'The Prayer for Dingana's Day December 16', which formed the basis of the hymn. This prayer is recorded in Gunner (2002) as follows:

This is a dreadful day, young girl of the rump of land that is Zululand. The cow was without its milker on that day ... The old women felt the trembling premonition of death in their hearts and called out to the boys, 'Leave them, our children, by whom will they be milked now the milkers are no more?' (p. 69)

This speech was made on the commemoration of the Battle of Blood River, and it adds an important piece of information regarding the hymn. In the hymn, there is no mention of the reason why the milkers are not present. As the hymn stands, an unknowing reader may surmise that the milkers could have gone to the mines to work, or they could have gone anywhere else. However, all that speculation happens because we do not know exactly what circumstances led to the composition of the hymn. The knowledge that is provided by the 'prayer' allows us to understand the hymn fully.

One of the methods Shembe employed in his drive to fight and criticise colonialism was to use in his hymns a deep language that at first glance seemed harmless but when observed closely and read in relation to its context proved to be highly political. This hiding of meaning is common in oral literature. Karin Barber (1999:29) has noted with regards to praise poetry that '... meanings are secreted in, attached to, or even withheld by, such texts through mechanisms that are not transparent and could not be deciphered without special knowledge'. For Shembe, however, this is not just a matter of convention. He knew that his subject matter was delicate and that it had to be rendered in a way that could be understood by his knowing audience but be inaccessible to his enemies.

However, it sometimes happens that an outsider's exegesis would understand a hymn to be political whilst, according to its internal interpretation, it is quite the contrary. One of the striking features of Isaiah Shembe's hymns is their duality of meaning: the fact that they can have different meanings if they are viewed from the inside (according to how they are understood inside the church) and when they are looked at from a literary perspective (normally by people outside the church). An example of this is hymn number 219:

$\begin{array}{ll}\text { Besilizwile we Babamkhulu } & \text { We have heard it, oh Babamkhulu } \\ \text { Sehlulwa wukwenza } & \text { We could not comply } \\ \text { We Babamkhulu } & \text { Oh Babamkhulu } \\ \text { Thambisa izwi lakho } & \text { Lighten your word [laws] } \\ \text { We Babamkhulu } & \text { Oh Babamkhulu } \\ \text { Sozama ukulenza izwi lakho. } & \text { We will try to keep your laws. } \\ \text { Izinkulungwane ngezigidi } & \text { Thousands and millions } \\ \text { Zimi lapha } & \text { Stand here } \\ \text { We Babamkhulu } & \text { Oh Babamkhulu } \\ \text { Zehlulwa yizwi lakho } & \text { They failed your word [laws] }\end{array}$

$\begin{array}{ll}\text { We Babamkhulu } & \text { Oh Babamkhulu } \\ \text { Thambisa izwi lakho } & \text { Lighten your word } \\ \text { We Babamkhulu. } & \text { Oh Babamkhulu. } \\ \text { Izwi leziboshwa } & \text { The word of the prisoners } \\ \text { We Babamkhulu } & \text { Oh Babamkhulu } \\ \text { Mawu lizwe izwi labo } & \text { May you hear their voice } \\ \text { We Babamkhulu } & \text { Oh Babamkhulu } \\ \text { Zifuna umphumuzi } & \text { They want a liberator } \\ \text { We Babamkhulu } & \text { Oh Babamkhulu } \\ \text { Lezo ziboshwa ziphumuze. } & \text { Those prisoners give them rest } \\ \text { Sihleli osizini } & \text { We live in sorrow } \\ \text { We Babamkhulu } & \text { Oh Babamkhulu } \\ \text { Kuleli lizwe } & \text { In this world } \\ \text { We Babamkhulu } & \text { Oh Babamkhulu } \\ \text { Yizinyembezi zodwa } & \text { It is all tears } \\ \text { We Babamkhulu } & \text { Oh Babamkhulu } \\ \text { Kuleso sigodi sosizi. } & \text { In this valley of distress. }\end{array}$

Taking into consideration the context in which these hymns were created, a South Africa where black people were oppressed and exploited, and looking especially at stanzas three and four, one hears the voice of a speaker who is concerned about the well-being of his or her people. The point of view of the speaker shifts from the first person to the third person, showing Isaiah Shembe's sense of self as separated from his followers and at the same time as part of them. The call for freedom and the need for rest meant so much to people whose land had been stolen from them and who were forced to work for the white farmers who had stolen their lands or else to move to urban areas where the living conditions were no better. Brown's (1999) views about this hymn are worth quoting at length:

In the context of social and discursive rupture, forms of worship in the separatist churches become expressions of their own meaning and value on the part of the dispossessed and displaced communities. A hymn like Shembe's No. 219 expresses the pain of social and spiritual experience and the longing for solace and restitution, even as it serves as a means of social empowerment claiming for black people the right of biblical interpretation and divine intervention. (p. 201)

The image of the prison is important as it is a place devoid of freedom and, for Isaiah Shembe, black people were forced to live like prisoners even if they were not incarcerated. The prison must have had special significance for Shembe since he himself had been imprisoned for his religious activities on many occasions. The level of suffering and distress that black people at large felt was sometimes worse than that experienced by prisoners. Stanza four is about 'this' world of sorrow where at least some people are always in tears. Here, the image of the prison is taken further to be 'the valley of distress' (isigodi sosizi), Isaiah Shembe's equivalent of hell, where even though people or spirits do not get burned, they live in constant suffering and pain as stated in hymn number 135:
Lapho abaning bemisiwe
Esigodini sosizi lokufa
Balindele umhla wokuphela
Where multitudes are stopped In the valley of sorrow of death Waiting for judgement day
Ukukhala nokugedla kwamazinyo. Thecrying and thedisappointment. 
However, this reading of hymn number 219 is far removed from that of amaNazaretha. The Nazaretha's understanding of this hymn is linked to the view that Isaiah Shembe's hymns came from heaven with the angels. Even if we as literary scholars do not believe in such a reading, I think it would be unwise to discredit it without any thought. As Barber (1999) states, in understanding texts (she is referring to praise poems):

... the first step must be to seek to establish as accurately as possible (always bearing in mind the impossibility of certainty and completeness in any such account) what the text could have meant or could have been taken to mean, in the context of its double relationship between its original author and audience. (p. 27)

I think that we should not exclude this part of exegesis even though I am not sure about the importance of it being the first step (for me it is a matter of making sure that it is recognised). Barber (1999) goes on to state that, '[a]ll other explanation, criticism or commentary must follow after this first indispensable step of interpreting the text 'on its own terms' (p. 27). In my case, I have provided an interpretation of this hymn in terms of what it may seem to an outsider, taking my cue from Duncan Brown's quote above. In Ibandla lamaNazaretha, rather than referring to the historical conditions in which black people were forced to live, this hymn's speakers are the late Nazaretha members who could not make it to heaven because they failed to comply with the laws of heaven that Isaiah Shembe had taught them.

Oral tradition in the church tells that, one day, Isaiah Shembe told his followers that he had taken a spiritual journey to heaven with the intention of ascertaining whether or not the members of the church who had passed away did make it to heaven. He wanted to know if they had made it to the special place he talks about in hymn number 10:

$\begin{array}{ll}\text { Umuzi wamaNazaretha } & \text { The home of AmaNazaretha } \\ \text { Lapha siyakhona } & \text { Where we are headed } \\ \text { Ukhazimula ngaphezu } & \text { It is brighter than } \\ \text { Kwelanga nenyanga. } & \text { The sun and the moon. }\end{array}$

According to this story, Shembe found many Nazaretha members stranded in the valley of distress, and when this encounter happened, the late members impugned Shembe for instituting laws so difficult that they could not comply with them. They were complaining that had he made the laws a little easier, they might have found themselves in heaven. In terms of this reading, the addressee of the hymn is Isaiah Shembe, generally referred to as 'Babamkhulu' by his followers. In stanzas one and two, these beings in the valley of distress are really begging Shembe to lighten the laws and allow them to enter heaven. They declaim that they did hear the laws, but these were too difficult for them. This hymn responds to another hymn in which Isaiah Shembe is the speaker, and he asks his followers why they had failed to execute the laws of heaven because he did deliver them to the people:

\footnotetext{
Ngamemeza ubusuku nemini Awungizwanga ngani?
}

I shouted day and night Why did you not hear me? $\begin{array}{ll}\text { Zizwe lalani uZulu ezwakale } & \begin{array}{l}\text { Nations go to sleep so Zulu will be } \\ \text { heard }\end{array} \\ \text { Phambi komsindisi. } & \text { Before the saviour. (Hymn number 45) }\end{array}$

This hymn seems to suggest that it was the other nations that prevented those members from paying attention to what Shembe was teaching while it also points to Zulu ethnicity in the church. In hymn number 45 , the addressee is allowed a voice to respond, but this voice tells a different story from that mentioned in hymn number 219. In hymn number 45 , the other nations are blamed for the failure of the people to comply with Shembe's laws: Ngavinjelwa yizo zonke izizwe/ Eziphansi kwezulu. [I was prevented by all the nations/ Under the earth].

The hardships about which the speakers are complaining in stanza three and four do not take place in this life but in the after-life. Since the prison is not physical but spiritual, the only one who can liberate the prisoners is the spiritual saviour, and according to members of the church, that is Isaiah Shembe. In terms of the church's understanding, however, the speakers are not begging to be liberated. Rather, they are demanding it. It is said that when Isaiah Shembe was narrating his story of the spiritual journey to heaven, he had a blue eye, and he told his followers that, amongst those people who were complaining against him, there was a minister who hurled a stone at him and gave him a blue eye.

\section{Zulu ethnicity in Isaiah Shembe's hymns}

Most scholars who have studied Ibandla lamaNazaretha and Isaiah Shembe emphasise the fact that Isaiah Shembe was concerned with restoring Zulu society to its former state and glory. Hexham (1994) states that:

We can safely say that the mission of Isaiah Shembe was to restore the dignity of the Zulu person and the independence of their country ... [His] aim was to restore his people to their previous glory and this he believed could be done on the basis of God's presence among the Zulu people in the same way as God had revealed his presence to ancient Israel. (p. xxvii)

In similar vein, the argument of Vilakazi, Mthethwa and Mpanza (1986) is that, in creating Ibandla lamaNazaretha, Shembe was trying to forge a new Zulu society, basing it on the old, pre-colonial one. About some of the hymns, Mpanza (1999) has this to say:

La magama uShembe wabe ewagambela isizwe samaZulu ukuba sithi uma sidumisa uNkulunkulu siwahlabelele, kodwa enomlayezo othile. Isihlabelelo 183 singumyalezo ngezizwe ezifuna izwe lakwaZulu. [These songs were created by Shembe for the Zulu nation to sing when they worship God, but they had a certain message. Hymn 183 is a message about the nations who want to take the land of the Zulu.] (p. 228)

Hymn number 183, about which Mpanza talks, is one of the most powerful and overtly political of Isaiah Shembe's hymns. The hymn is addressed to the Zulu people and tries to alert them to the problem of being led by outsiders in their 
native land: Lalela Zulu/ Lalela abantu bengiphethe/ Ngezwe lethu. (Listen Zulu/Listen to people ruling me/About (In) our land.) Here Isaiah Shembe challenges white domination and the idea of the civilising mission. For him, what the white people brought to (South) Africa was destruction, certainly because it brings sorrow to the native people and allows the outsiders to rule the native people. He likens them to the weaver bird (ihlokohloko), notorious for destroying people's fields:

$\begin{array}{ll}\begin{array}{l}\text { Siyazizwa izizwe zivungama } \\ \text { Zivungama ngawe } \\ \text { Njenge nyoni. }\end{array} & \begin{array}{l}\text { We hear the nations grumbling } \\ \text { Grumbling about you } \\ \text { Like a bird. }\end{array} \\ \begin{array}{ll}\text { Sish'izinyoni sish' amahlokohloko } \\ \text { Ayicekezel' insimu }\end{array} & \begin{array}{l}\text { We mean the birds, the weaver } \\ \text { birds }\end{array} \\ \text { KaDingana benoSenzangakhona. } & \begin{array}{l}\text { They destroyed Dingana's and } \\ \text { Senzangakhona's field. }\end{array} \\ \begin{array}{l}\text { Bayiqedile mamo } \\ \text { Sizwango Mnyayiza } \\ \text { KaNdabuko. }\end{array} & \begin{array}{l}\text { They destroyed it completely } \\ \text { We heard from Mnyayiza } \\ \text { Son of Ndabuko. }\end{array}\end{array}$

The metaphor of the fields and the weaver birds refers to the South African land that the white people have confiscated and made their own as the weaver birds invade people's fields and feed on what is sowed there as if it belongs to them. It also refers to all the destruction caused to South African people by the colonial settlement. According to the hymn, the fields that are destroyed belong to Dingana and Senzangakhona even though the white people lived all over South Africa and their actions impacted on all the black people.

However, it is my contention in this article that, even when Shembe used the Zulus as the speaker or addressee in his hymns, his vision went beyond Zulu tribalism. He dealt with much broader issues concerning the whole of Africa. The above hymn could be read alongside Kofi Awoonor's (a poet from Ghana) poem 'The Weaver Bird'. Not only does Awoonor's poem deal with issues similar to those in Shembe's hymn, but they also use the same metaphor to refer to the white people's settlement in Africa and the impact that colonialism and the mission project have on the African people. In Awoonor's poem, we are told that the 'weaver bird' built its nest in the speaker's house, and because they did not chase it away, it came back 'in the guise of the owner/ Preaching salvation to us that owned the house.' In both texts, the weaver bird, the white people, impact negatively upon the continent and its people. As Shembe claims in his hymn that the weaver bird destroyed Dingana's field, the speaker and his or her people in Awoonor's poem '... look for new homes everyday/ For new alters [they] strive to rebuild/ The old shrines defiled by the weaver's excrement' (Awonoor 2002:191).

\section{African nationalism in Isaiah Shembe's hymns}

The point made above, that Shembe's poems that seem to be concerned with Zulu tribalism need to be understood in broader terms as directed to all African people, is validated

by the fact that a number of Isaiah Shembe's hymns are addressed not just to the Zulus but to Africans. This is fitting because even though Ibandla lamaNazaretha was to become a predominantly Zulu church, something which I believe had more to do with the laws of apartheid than Shembe's intention, there is evidence to suggest that it did not begin as such. For instance, Ndwedwe magistrate, Mckenzie (quoted in Papini 1999), wrote in January 1923:

It must be remembered that [Shembe] is the head of a large following of mixed natives, and there is always a danger, whatever Tshembe's present attitude may be, of his organisation, being in the future, made use of by agitators for political purposes. (p. 250, emphasis in the original)

The fact that Shembe was heading a large following of 'mixed natives' is important for my argument in this section because I wish to argue and demonstrate that Isaiah Shembe was not simply speaking to the Zulus or only concerned about their well-being. There is a sense in which he saw himself as an African speaking to other Africans. Writing about what he calls 'Zulu specificity', I think Brown (1999) is correct to say that:

Isaiah Shembe's hymns seem to me themselves to call into question any simplistic co-option of Zulu history in the cause of ethnic separatism, however, since they place Zulu dispossession in a broader Africanist context. The early history of Shembe parallels that of the SANNC, forerunner to the ANC, formed in 1912. Shembe's friend and biographer, John Dube, was a prominent member of the SANNC, and his vision of a nationalism across tribal divisions appears in certain ways to have impinged upon the church of the Nazarites, although without displacing the church's ethnic specificities. (p. 212)

The hymns that I discuss in this section show that Shembe's work and concern went beyond Zulu specificity. Hymn number 46, for instance, warns Africans about their oppression at the hands of colonialism - that it enslaves them and makes them a laughing stock to other nations:

\section{Phakama Afrika \\ Funa uMsindisi \\ Kuseyisikhathi esihle \\ Ziyakushiy' izizwe. \\ Phakama Afrika \\ Funa uMsindisi \\ Namhla uyisihlekiso \\ Sazo zonk' izizwe.

Phakama Afrika
Funa uMsindisi
Namhla siyizigqili
Nezigqilikazi.

Phakama Afrika

Funa uMsindis

Namhla siyizigqwashu

Zokwesula izinyawo zezizwe.

Phakama Afrika

Funa uMsindisi

\author{
Rise up Africa \\ Seek your Saviour \\ It is still good time \\ Nations leave you behind
}

Rise up Africa

Seek your Saviour

Today you are a laughing stock Of all the nations.

Rise up Africa

Seek your Saviour

Today we are slaves

And female slaves.

Rise up Africa

Seek your Saviour

Today we are door-mats

For wiping other nation's feet.

Rise up Africa

Seek your Saviour 
Namhla amadodakazi akho Ayizigqili zezizwe.
Today your daughters Are slaves of other nations.
This hymn tries to raise consciousness amongst Africans about their situation, and it proposes that only a strong religious leader like Shembe can help liberate them. The Africans are pitted against the other nations, the white people to be sure, who are said to be better off than they in terms of knowing their saviour who can liberate them. The rebellion that the Africans are incited to embark upon and the image of slavery, especially, which is mentioned a number of times in the hymn are both foreign concepts about which Shembe is likely to have read in the Bible and perhaps other texts. Even though slavery may have existed in Africa before, Shembe is unlikely to have had any first-hand knowledge of it since it did not exist in South Africa.

It seems to me that one of the things that attracted Isaiah Shembe to the concept of the Zulu nation was the work that Shaka had done in forging a strong nationalism and his vision of bringing all the black nations under one leadership. J.G. Shembe, Isaiah Shembe's son and successor, said this in his tape-recorded sermon in eKuphakameni in 1968:

Abanye abantu baye bathi uShaka kwaku wuSathane. Sonke nje sikhule kushiwo njalo ezikoleni kuthiwa wuSathane uShaka. Kodwa uShembe ufike wathi uShaka kwakuyingelosi kaNkulunkulu. Wayethunywe eZulwini ukuba azogeza abantu abamnyama ezonwenizabo. Wayengazi ke ukuthi kwenziwa kanjani lokho, wayekwenza ngomkhonto yena. Wayebageza ngomkhonto. Ezobenza futhi bathandane. Badle ngakhezo lunye. Ngiye ngifise sengathi uShaka engabuye avuke, aphinde akwenze futhi lokho. Kulokhu kwenyanyana kwabantu okungaka. Nalokhu kuzondana okungaka. Kodwa uShaka wabashiya abantu bakwaZulu bethandana kumuntu munye. [Some people say Shaka was Satan. When we all grew up it was said in schools that Shaka was Satan. But Shembe said Shaka was an Angel of God. He was sent from heaven to cleanse black people from their sins. He did not know how to do that so he did it by the spear. He cleansed them by the spear. He also came to make them love one another. Eat with one spoon. Sometimes I wish that Shaka could be resurrected and repeat what he did. In this hatred people have for one another! But Shaka left the Zulus loving each other as one person.]

Whilst Shaka used force and violence in his attempt to create and expand his kingdom, an able religious leader would use spiritual power to attract people peacefully. Shembe really loathed violence, and one of the reasons why he disliked white colonialists was the pain and violence they inflicted on black people in the colonial wars, especially in the Battle of Blood River, about which he composed a hymn as noted above, and the Anglo-Zulu War.

In the same way as 'Phakama Afrika', hymn number 17, 'Oshaywayo Akalahlwa' [The one who is beaten is never forsaken], talks to the Africans and urges them to open their eyes to see their predicament. Brown (1998:153) remarks that '... [i]n its language of protest and resistance, this hymn anticipates the black consciousness (BC) rhetoric of poets such as Ingoapele Madinguane, Mongane Wally Serote, Mafika
Gwala and Sipho Sephamla'. Whilst this hymn shows that Shembe did not see himself as just a Zulu prophet (if he saw himself as a prophet at all) but as one sent to all black people, it also points to his shifting reference to African people, at times calling them Zulus, sometimes South Africans and on occasion referring to them as Africans:

\begin{tabular}{|c|c|}
\hline Oshaywayo akalahlwa & $\begin{array}{l}\text { The one who is beater } \\
\text { forsaken }\end{array}$ \\
\hline Makangazideli & Let him/her not lose hop \\
\hline Phaphamani phaphamani & Wake up, wake up \\
\hline Nina maAfrika. & Wake up you Africans. \\
\hline Imbombo zokhothamo & The archways of the do \\
\hline Zithobisa wena & Make you stoop \\
\hline Phaphamani phaphamani & Wake up wake up \\
\hline Nina maAfrika. & You Africans. \\
\hline Izitha zika Jehova & The enemies of Jehovah \\
\hline Zivukela wena & Rise up against you \\
\hline Phaphamani phaphaman & Wake up, wake up \\
\hline Nina maAfrika. & You Africans. \\
\hline
\end{tabular}

Textually both hymn number 17 and hymn number 46 are typical of all Shembe's hymns in that they have only a few stanzas made up of only a few lines. In this case, they both have five stanzas made up of four lines, which renders them easily performed in a call and response style that is also typical of Isaiah Shembe's hymns. These hymns are not praises to God (there is no mention of God or Jesus in either of them) but are Shembe's reflections on his condition as a human being. The point of view of the speaker shifts from second person to third person to first person plural, reflecting Shembe's ambiguous relationship with his followers: At times, he considers himself part of his followers, and sometimes, he is apart from them. However, the feature that marks these hymns as similar, and which is even more significant, is the refrain that obtains in both of them. This refrain serves to drive home Shembe's message and, at the same time, enhancing the hymn's 'performativity'. Both the refrains 'Wake up, wake up/You Africans' and 'Rise up, Africa/Seek your saviour' show that Shembe's addressee are Africans, and the Africans are not only warned about their situation, but they are also called upon to take action in order to liberate themselves. The refrains also create rhythm when these hymns are performed.

\section{Conclusion}

Whilst it is important to note the political involvement evinced in Shembe's hymns as discussed above, it is not to say that Ibandla lamaNazaretha should be seen simply as a political movement. The politics of South Africa in the early 1900s affected and concerned Shembe so much that he had to deliberate and deal with it through song and performance; through the language well-known to him. What is, however, perhaps more important is that he provided his own people (Black people in South Africa, especially the Zulus) with an alternative world view to that of the West. Whilst in orthodox churches black people needed to jettison their African ways - 
the houses they lived in, the kind of dress they were used to and their customs - Isaiah Shembe offered them a place where they could worship God without having to alter their identity as much as they were compelled to do in missionary churches. My point here is that, despite the fact that these hymns respond to certain political issues that concerned Shembe, the hymns are not generally about politics. They are hymns or songs of worship designed to be performed in religious services, and they deal with the spiritual needs of Shembe himself and his followers.

It is true that, even today, Ibandla lamaNazaretha is predominantly a Zulu church because, although there are many people in the church who belong to other ethnic groups in South Africa and beyond, Zulus far exceed other members in number and because the church's foundational texts, especially the hymn-book, is still not available in any African language except isiZulu. My contention in this article is that this was not Isaiah Shembe's design. It happened as a result of the seclusion of the races that was prevalent in the country at the time. It seems to me that, had apartheid not been introduced in South Africa, the church would have had more members from other groups in South Africa as McKenzie's report claimed that Shembe was a leader of 'mixed natives'. Also, it is known that there were a few Indian members of the church in the time of Isaiah Shembe and early in J.G. Shembe's ministry (one of these was called Nozinkobe), but they disappeared after the tightening of apartheid laws in the 1950s or 1960s. That said, I conclude by suggesting that Isaiah Shembe's hymns are indeed literary texts and should be read alongside the poems of great African poets like Kofi Awonoor and B.W. Vilakazi as they present a similar kind of vision and concern for the plight of black people in South Africa and beyond.

\section{Acknowledgements}

\section{Competing interests}

The author declares that he has no financial or personal relationship(s) that may have inappropriately influenced him in writing this article.

\section{References}

Awonoor, K., 2002, 'The weaver bird', in H. Moffet \& E. Mphahlele (eds.), Seasons come to pass: A poetry anthology for Southern African students, p. 191, Oxford University Press, Cape Town.

Barber, K., 1999, 'Obscurity and exegesis in African oral praise poetry', in D. Brown (ed.), Oral literature and performance in Southern Africa, pp. 27-49, James Currey, Oxford

Barber, K. \& Furniss, G., 2006, 'African-language literature', Research in African Literatures 37(3), 1-14. http://dx.doi.org/10.2979/RAL.2006.37.3.1

Brown, D., 1998, Voicing the text: South African oral poetry and performance, Oxford University Press, Oxford.

Brown, D., 1999, 'Orality and Christianity: The hymns of Isaiah Shembe and the Church of the Nazarites', in D. Brown (ed.), Oral literature and performance in Southern Africa, pp. 195-219, James Currey, Oxford.

Comaroff, J. \& Comaroff, J., 1991, Of revelation and revolution: Christianity, colonialism and consciousness in South Africa, University of Chicago Press, Chicago. http:// dx.doi.org/10.7208/chicago/9780226114477.001.0001

Gerard, A.S., 1971, Four African literatures: Zulu, Sotho, Xhosa and Amharic, University of California Press, Berkeley.

Gunner, E., 1988, 'Power house prison house: An oral genre and its use in Isaiah Shembe's Nazarite Baptist Church', Journal of Southern African Studies 14(2), 204-227.

Gunner, L. (ed.), 2002, The man of heaven and the beautiful ones of God: Isaiah Shembe and the Nazareth Church, transl. L. Gunner, University of KwaZulu-Natal Press, Pietermaritzburg.

Hexham, I. (ed.), 1994, The scriptures of the AmaNazaretha of Ekuphakameni: Selected writings of the Zulu prophets Isaiah and Londa Shembe, transl. L. Shembe \& H.J. Becken, University of Calgary Press, Calgary.

Mathonsi, N., 2004, 'Aspects of social commitment in oral literature', South African Journal of African Languages 24(1), 46-56.

Mpanza, M., 1999, Izwi Lezulu, Excellentia Publishers, Empangeni.

Mphahlele, E., 1992, 'Landmarks of literary history in South Africa: A black perspective', in M. Chapman, C. Gardener \& E. Mphahlele (eds.), Perspectives in South African English literature, pp. 37-59, Ad Donker (PTY) Ltd, Parklands.

Muller, C. (ed.), 2010, Shembe hymns, transl. B. Mthethwa, University of KwaZuluNatal Press, Pietermaritzaburg.

Oosthuizen, G.C. \& Hexham, I. (eds.), 1999, The story of Isaiah Shembe: Early regional traditions of the acts of Nazarites, transl. H.J. Becken, Edwin Mellen Press, Lewiston.

Papini, R., 1999, 'Carl Faye's transcript of Isaiah Shembe's testimony of his early life and calling', Journal of Religion in Africa 29(3), 243-284. http://dx.doi. org/10.1163/157006699X00340

Sithole, N., 2011, 'Performance, power and agency: Isaiah Shembe's hymns and the sacred dance in the Church of the Nazarites', PhD Thesis, Department of English, University of KwaZulu- Natal, Pietermaritzburg.

Sithole, N., 2012, 'African languages literature: Childish and immature?: The case of two IsiZulu novels', Current Writing 25(1), 50-57. http://dx.doi.org/10.1080/101 3929X.2012.645359

Shembe, J.G., 1940, Izihlabelelo ZamaNzaretha, W.H. Shepherd, Durban.

Shembe, J.G., 1968, 'Sayuli', tape-recorded sermon, Inanda.

Sundkler, B.G.M., 1961, Bantu prophets in South Africa, Oxford University Press, London.

Sundkler, B.G.M., 1976, Zulu Zion and some Swazi Zionists, Oxford University Press, Oxford.

Vilakazi, A., Mthethwa, B. \& Mpanza, M., 1986, Shembe: The revitalisation of African society, Skotaville Publishers, Johannesburg. 